\author{
Agnieszka GONTASZEWSKA-PIEKARZ \\ Jerzy KŁOSIŃSKI ${ }^{2}$
}

\title{
GEOLOGICAL AND SEISMIC INVESTIGATION OF FORMER LIGNITE MINING AREA IN ZIELONA GÓRA - TWO CASE STUDIES
}

\begin{abstract}
The article presents two case studies of investigation carried out on plots of land, intended for multi-family residential development, lying on a former lignite mining area in Zielona Gora. It was underground mining, operating in the years 18401948. Lignite deposits were extracted with the room and pillar method, i.e. with an overlayer collapse, causing deformations on the surface of the ground. In the first case study, there was no detailed mining data. In order to identify the geological structure under the planned seven-floor multi-family building, seismic surveys were performed with the technique of multichannel analysis of surface waves (MASW). Three seismic profiles were performed. They revealed the presence of several zones where $S$-waves had smaller velocity values. In order to verify whether the zones with the smaller values of velocity correspond to e.g. lower soil density resulting from collapsed exploitation room, some drillings were undertaken to the depth indicated in geophysical investigation. Additionally, the CPT and dynamic probing were also performed. The data obtained allowed to determine the soil parameters necessary for the safe design and foundation of the building. In the second case study, a historical mining map with the marked location of the shaft and the main galleries was used. Formerly, geological and engineering documentation for construction works had been prepared, based on 30-meter drillings and soundings with a heavy probe. The mining maps and the contemporary maps were mapped one on another carefully and accurately, calibrated with historic buildings. Thus, the accuracy of $5 \mathrm{~m}$ was obtained. Additionally, investigation with the MASW technique was performed. Ten seismic profiles were performed, and then verified by drillings. Also, dynamic probing in the vicinity of the expected location of the shaft was performed. Neither the MASW investigation nor the dynamic probing did not reveal any alterations in the soil condition, which would suggest the presence of the properly liquidated shaft. Thus, based exclusively on the cartographic material, the area comprising the liquidated and backfilled shaft was established. The area was excluded from the plans for the intended building erection.
\end{abstract}

Keywords: lignite mining, Zielona Góra, seismic investigation, multichannel analysis of surface waves MASW, seismic estimation SPT (N30)

\footnotetext{
${ }^{1}$ Corresponding author/autor do korespondencji: Agnieszka Gontaszewska-Piekarz, Instytut Budownictwa, Uniwersytet Zielonogórski, ul. Prof. Szafrana 1, 65-001 Zielona Góra, a.gontaszewska@ib.uz.zgora.pl

2 Jerzy Kłosiński, Geospectrum S.c. Kraków, klosinski@geospectrum.pl
} 


\section{Introduction}

The underground lignite mining was a rare phenomenon in Poland and was restricted to Western Poland, mainly to Lubusz Land and Lower Silesia, although the bibliography describes mines in Greater Poland [12,15]. There are few works which considered the issues of hazards arising from this exploitation. They focused mainly on the inventory of the existing deformations and the analysis of archival materials $[2,13]$. It was not until the twenty first century that the areas of the former lignite mining became objects of interest, mainly due to the expansion of residential construction onto the suburbs. Sinkholes, which occur from time to time, forced the owners or the local authority to undertake geological and geophysical investigations. Such a situation occurred in the area of Tuchola [12] and Zielona Góra. In recent years, there have been at least 4 sinkholes there, of which 2 are attributed to the presence of shafts (ventilation shaft and an inconsiderable descending gallery), and the genesis of the other has not been fully explained $[7,17]$.

The first deformations of the ground surface in the region of Zielona Gora are as old as the lignite extraction. However, because it was conducted primarily in the woodlands and on agricultural lands, they did not constitute any threat. In the case of extraction in built-up areas, protective pillars were designed under individual buildings. There is no information about any construction disasters related to mining.

Until the 1990s, the post-mining areas (their range was known) remained undeveloped. Currently, they have been turned into land intended for construction, which particularly refers to the suburban areas. Recently, comprehensive geological and geophysical surveys have been carried by authors in several premises within the town area in relation to the planned erection of buildings.

The investigations aimed at determination whether the subsoil for the planned buildings did not contain voids (old workings), or any layers with smaller density resulting from void-collapses.

\section{Lignite mining in Zielona Góra}

Lignite was discovered in the surroundings of Zielona Góra (south to the city) in 1838. On 24th of November 1840, a lignite mining enterprise was founded. It was named "Friedrich Wilhelm". The enterprise was then transformed into a company "Consolidierte Grünberger Gruben". The extraction, from shaft "Emilie" was commenced in October, 1841 [6,14]. Lignite production amounted to approximately 1 million hectoliters (100 000 tones) per year until World War II. The lignite was primarily used in steam engines in the factories and the spinning mills of Zielona Gora. After the Second World War, the production was resumed, but in 1948 the mine was closed down. Lignite of "Consolidierte Grünberger Gruben" was mined on the area which now lies within the 
Zielona Góra borders, and then it was systematically shifted to the west, toward the village of Wilkanowo and Słone. In the 1920th, the extraction was concentrated between the present streets Wojska Polskiego and Łużycka. In the subsequent years, the lignite deposits were exploited mainly to the south of the present Łużycka Street. In the 1930th, lignite was mined beyond the borders of Zielona Góra (Fig. 1). The history of Zielona Góra lignite mining was described in details by the author in, inter alia, [6]. Apart from „Consolidierte Grünberger Gruben" company, there were a dozen smaller mines operating mainly in the 19th century.

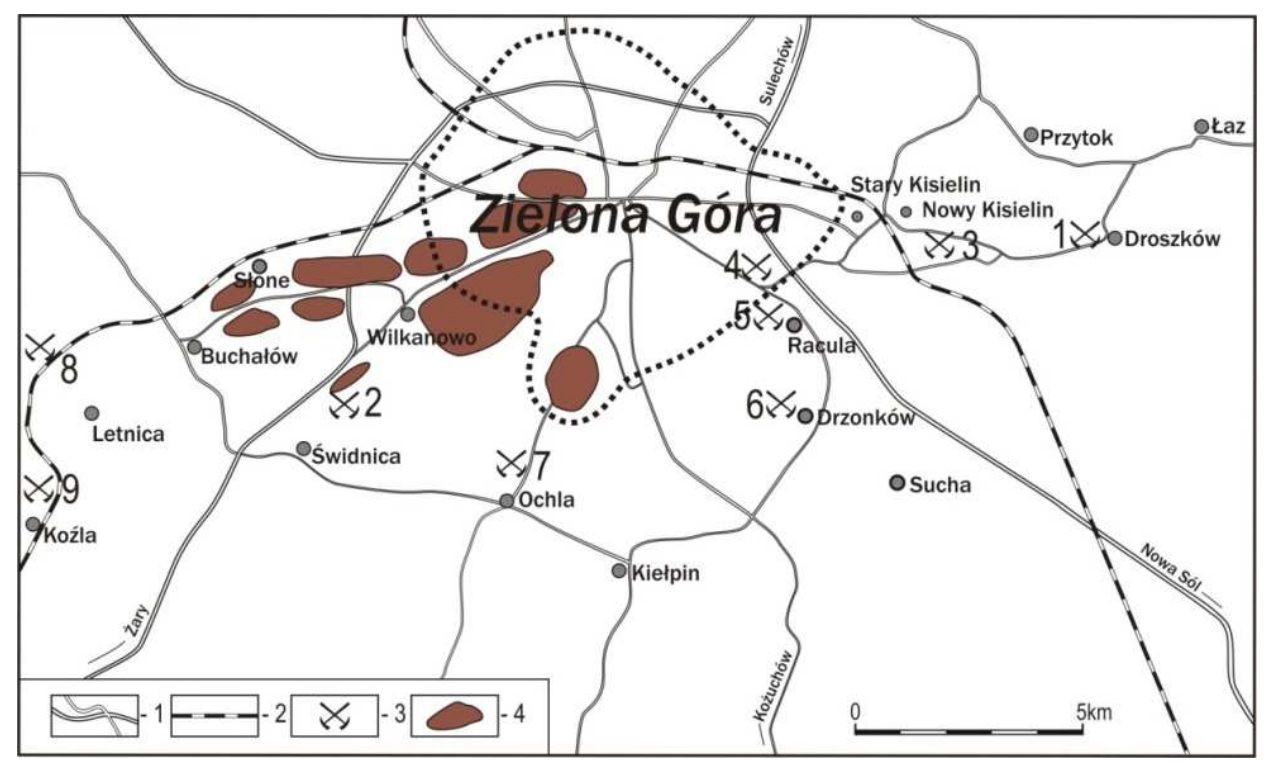

Fig. 1. Lignite mines near Zielona Góra - 1 - roads, 2 - railways, 3 - mine, 4 - exploitation area of "Consolidierte Grünberger Gruben”. Other mines: 1-Ferdinand, 2-Zukunft, 3- Langerschnt-Glück,4- Mathilde,5- Förster, 6- Johann Carl, 7- Glückauf, 8-Consolidierte Carl, 9-Cosel [5]

Rys. 1. Kopalnie węgla brunatnego w okolicy Zielonej Góry - 1 - drogi, 2 - kolej, 3 - kopalnie, 4 - tereny eksploatacji „Consolidierte Grünberger Gruben”. Inne kopalnie: 1-Ferdinand, 2-Zukunft, 3- LangerschntGlück,4- Mathilde,5- Förster, 6- Johann Carl, 7- Glückauf, 8-Cons. Carl, 9-Cosel [5]

The majority of lignite deposits, which were exploited before the war, was found in glaciotectonic disturbed structures. In the case of Zielona Gora, the lignite deposits occur within the moraine formed during the Warta glaciation, called Wał Zielonogórski. Glaciotectonic structure was of a prior importance for the availability of the deposits. Before the war, lignite was mainly extracted from glaciotectonic disturbed structures, where the deposits, originally occurring at considerable depths, were "squeezed" towards the surface in a form of anticlines or saddles. The subject of the mining operation was the layer called "1. środkowopolski", also called in Western Poland as "Henryk" layer, and in the 
pre-war German literature - "Oberflöz". The overburden of the layer consists prevail clays of Poznan formation. Their characteristic feature is the discontinuity of their layers, varying volume and declines (up to vertical). The volume of the Zielona Góra deposits amounts not more than 3-4 m.

The deposit was accessed through shafts, slopes or horizontal galleries which were later used to transport the excavated material onto the surface. In the Zielona Góra mines, the shafts (vertical) were usually built in the highest points of the saddles and then they were adjusted to the geological structure of the particular deposit. The shafts were of square or rectangular cross-sections, with the area of up to $20 \mathrm{~m}^{2}$. The applied casings were made of brick, concrete or wood (where only short, several-year exploitation was envisaged). Next, shaft sump and transportation galleries were performed. The galleries were built in the bed floor every 20-30 m [3]. Due to the frequent occurrence of saturated sands, both in the ceiling and the footwall of the deposit, lignite was avoided to be broken through. The lignite deposit was divided into respective fields. The extraction of the deposit started at the border of the field and then moved backwards to the main gallery.

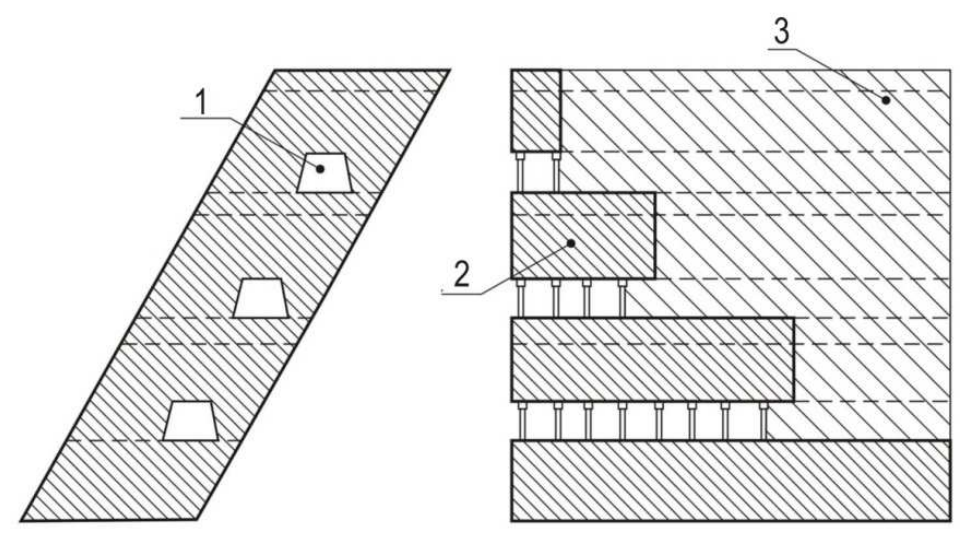

Fig. 2. Exploitation in steep layer with small thickness (based on [8]); 1-exploitation gallery, 2 -lignite, 3-collapsed space

Rys. 2. Eksploatacja w stromym pokładzie o niewielkiej grubości (na podstawie [8])

Lignite was extracted with the room and pillar method [4]. In this method, the lignite is extracted in rooms where protective pillars of unextracted lignite are left behind $[8,12]$. Where lignite deposits are steeply sloped, the galleries were constructed one over another (Fig. 2), and the extraction was carried downwards. Such galleries were interconnected with shafts in which the extracted lignite was dumped down, and then to the main gallery along which the extracted lignite was transported to the shaft sump. The volume of exploitation in a room did not usually exceed $5 \mathrm{~m}$, and the room itself was as big as $3 \times 4$ up to $4 \times 5$ 
$\mathrm{m}$, and it rearly reached the size of $30 \mathrm{~m}^{2}$. During the extraction process, the roof was protected with a wooden casing (with roof bars, stands and cladding). After the extraction process was terminated, the wood was robbed, which caused the collapse of roof layer. When it was necessary, the room was blocked with flood protection damns, especially in the case of the occurrence of saturated sands at the top of the seam. After the collapse of the roof layer followed by fragmented rock mass collapse, the extraction was continued $[8,10]$. However, it may be assumed that some remaining of the wooden casing might have been left over in the old rooms, and they might have persisted until today in favorable conditions (under water) [12].

\section{Methodology}

Due to inconsiderable sizes of galleries and exploitation rooms, it was impossible to determine their layout in the subsoil with drillings. It was necessary to use geophysics methods. The authors decided to use the MASW technique.

The multichannel analysis of surface waves (MASW) method is one of the seismic survey methods evaluating the elastic condition (stiffness) of the ground for geotechnical engineering purposes. MASW first measures seismic surface waves generated from various types of seismic sources (such as sledge hammer) analyzes the propagation velocities of those surface waves, and then finally deduces shear-wave velocity (Vs) variations below the surveyed area that is most responsible for the analyzed propagation velocity pattern of surface waves. Shear-wave velocity (Vs) is one of the elastic constants and closely related to Young's modulus. Under most circumstances, Vs is a direct indicator of the ground strength (stiffness) and therefore commonly used to derive load-bearing capacity. After a relatively simple procedure, final Vs information is provided in 1-D or 2-D.

MASW is one of the modern and the easiest near-surface shallow seismic methods that provides highly favorable and competent results. Data acquisition is significantly more tolerant in parameter selection than any other seismic methods because of the highest signal-to-noise ratio $(\mathrm{S} / \mathrm{N})$ easily achieved. This most favorable $\mathrm{S} / \mathrm{N}$ is due to the fact that seismic surface waves are the strongest seismic waves generated that can travel much longer distance than body waves without suffering from noise contamination. Additionally MASW discriminates useful signal from harmful noise, then assures an increased resolution when extracting signal in the midst of noise that can be anything from natural or cultural activities to other types of inherent seismic waves generated simultaneously (higher-mode surface waves, body waves, bounced waves, etc.) 


\section{Investigation of post-mining areas - case study 1}

On a plot in Prosta Street in Zielona Góra (Fig. 3), three multi-family, 4floor buildings are planned to be erected. The maximum depth of foundation is planned at $-5,02 \mathrm{~m}$, and the expected load for soil qfn $=210 \mathrm{kPa}$.

The southern part of the plot (now forested) was the area of a former underground lignite extraction. The exploitation took place within 1878-1884 with the following shafts: Schacht 23, Förderschacht and Versuchschacht. No data relating the layout of the galleries has remained. However, the area of lignite extraction is known from maps from the 1930s (Fig. 4). The detailed locations of the shafts have not been established, despite the numerous trials to calibrate the maps. The failure to properly calibrate the maps was due to the fact that there were no other buildings in the considered area - the mine was situated outside the former borders of the town. It may be inferred from both the careful analysis of the mining maps and the remained cross-sections (Fig. 5), that lignite deposit was mined form the saddle situated in the (c.a.) east - west direction. The southern wing went downward under a slight angle, whereas the northern wing was almost vertical. The shafts were located to the north from this wing or directly in it. Thus, it may be assumed that the location of the shafts suggests the northern reach of the exploitation. The deepest exploitation gallery was located on the level of $88.33 \mathrm{~m}$ a.s.l. (depth of about $50 \mathrm{~m}$ ).

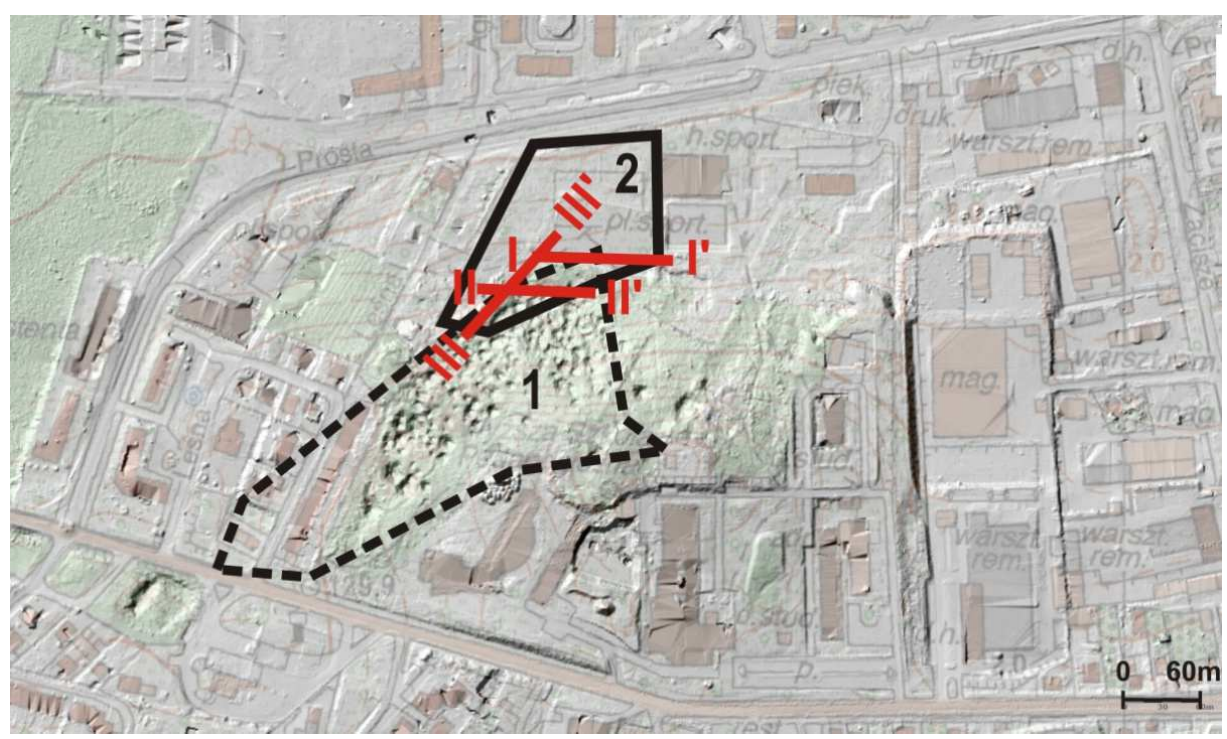

Fig. 3. Surface topography of Prosta Street from laser scanning (LIDAR). 1 - exploitation area, 2 -investigated area. Seismic profiles are marked. Map source: geoportal.gov.pl

Rys. 3. Powierzchni terenu okolic ul. Prostej w obrazie skanningu laserowy (LIDAR). 1 - zasięg eksploatacji, 2 - badany teren, zaznaczono linie profili sejsmicznych. źródło mapy: geoportal.gov.pl 


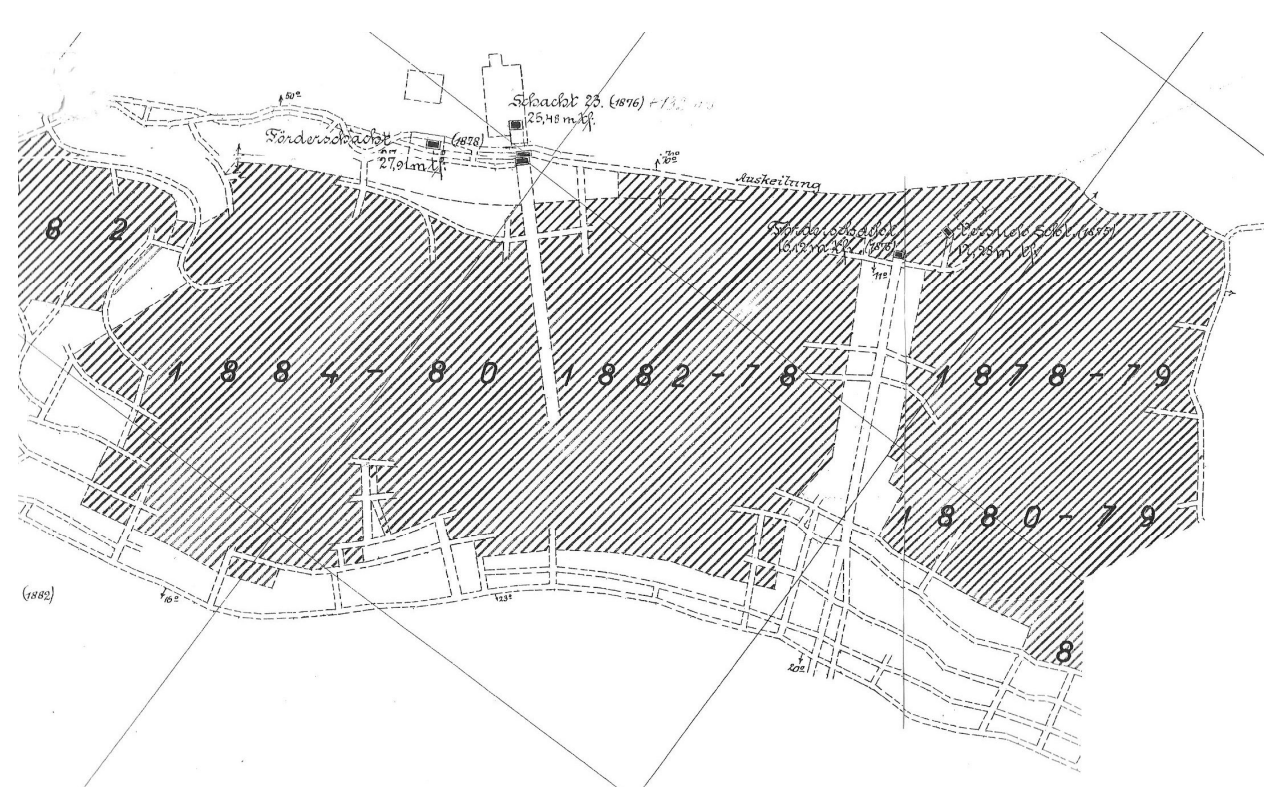

Fig. 4. Mining map, scale 1:1000. Shafts (with its depth), main mine galleries and exploitation dates are marked

Rys. 4. Fragment mapy górniczej w skali 1:1000. Zaznaczono szyby wydobywcze wraz głębokością, główne chodniki oraz lata eksploatacji

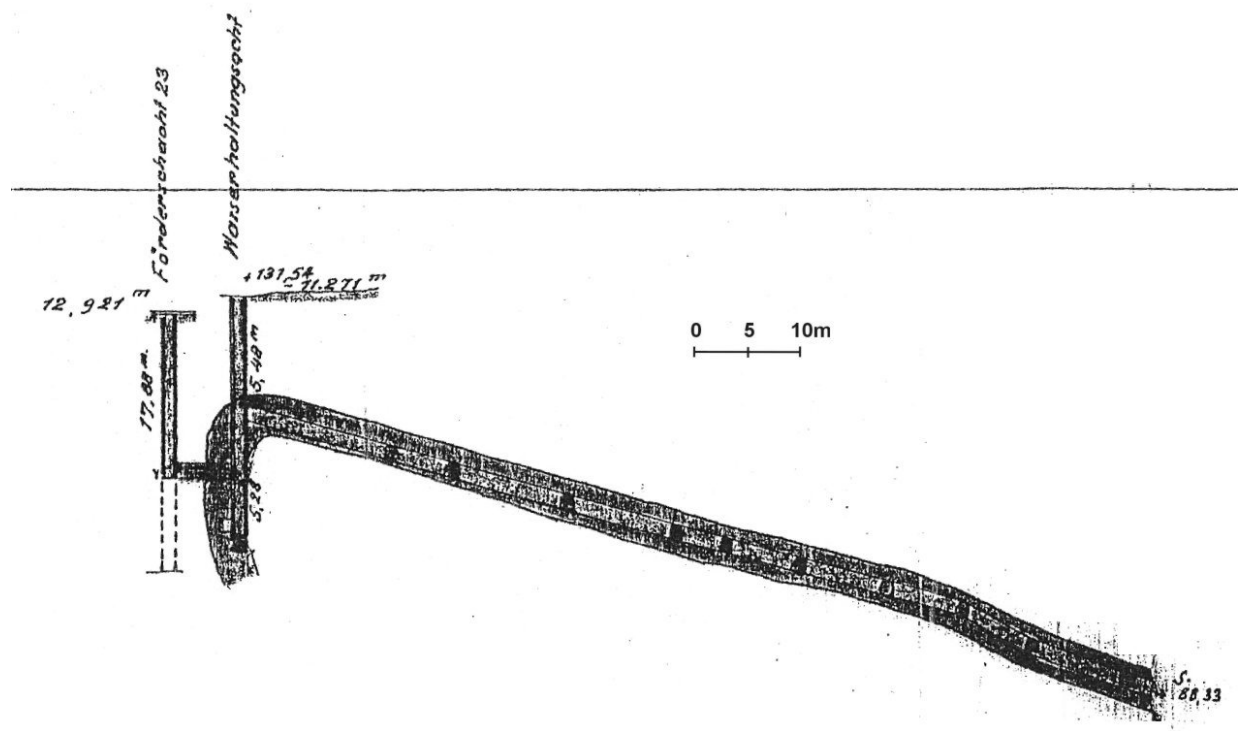

Fig. 5. Schematic cross-section of Shaft 23 and its lignite layer

Rys. 5. Przekrój przez szyb 23 oraz pokład eksploatowany tym szybem 
Directly to the south from the area intended for the buildings, a considerable number of deformations are found, mainly of a circular shape, with the diameter of about $2-4 \mathrm{~m}$ and the approximate depth of $1 \mathrm{~m}$. They can be perfectly seen in the laser scanning image (Fig. 3). The most important objective of the investigation was to establish the northern border of the exploitation area. In order to do so, the following actions were performed: ten drillings to the depth of $10-20 \mathrm{~m}$, dynamic probing and static probing down to the depth of $13-21 \mathrm{~m}$.

The drillings and the CPT probing allowed a detailed identification of the geological structure of the area. The following was found: the occurrence of fine sands (mainly in the top of the layer) and medium sands (partly mixed with gravel), in a compacted state. The thickness of the sands amounts, at least, $10-20 \mathrm{~m}$, their (probable) floor was reached only in one point, at the depth of $17.5 \mathrm{~m}$. In two points, sandy clay or loamy sand interbeddings were found. Beneath the clays, Miocene sediments should be found, lignite including, but the performed drillings did not reach their roof. The CPT probing did not reveal any zones of poorer compaction which could be correlated with the loosened soil over the workings. A free surface of the water table was found at the depth of $12.5-17.0 \mathrm{~m}$ under the ground, accompanied by the flow of underground water in the southern direction.

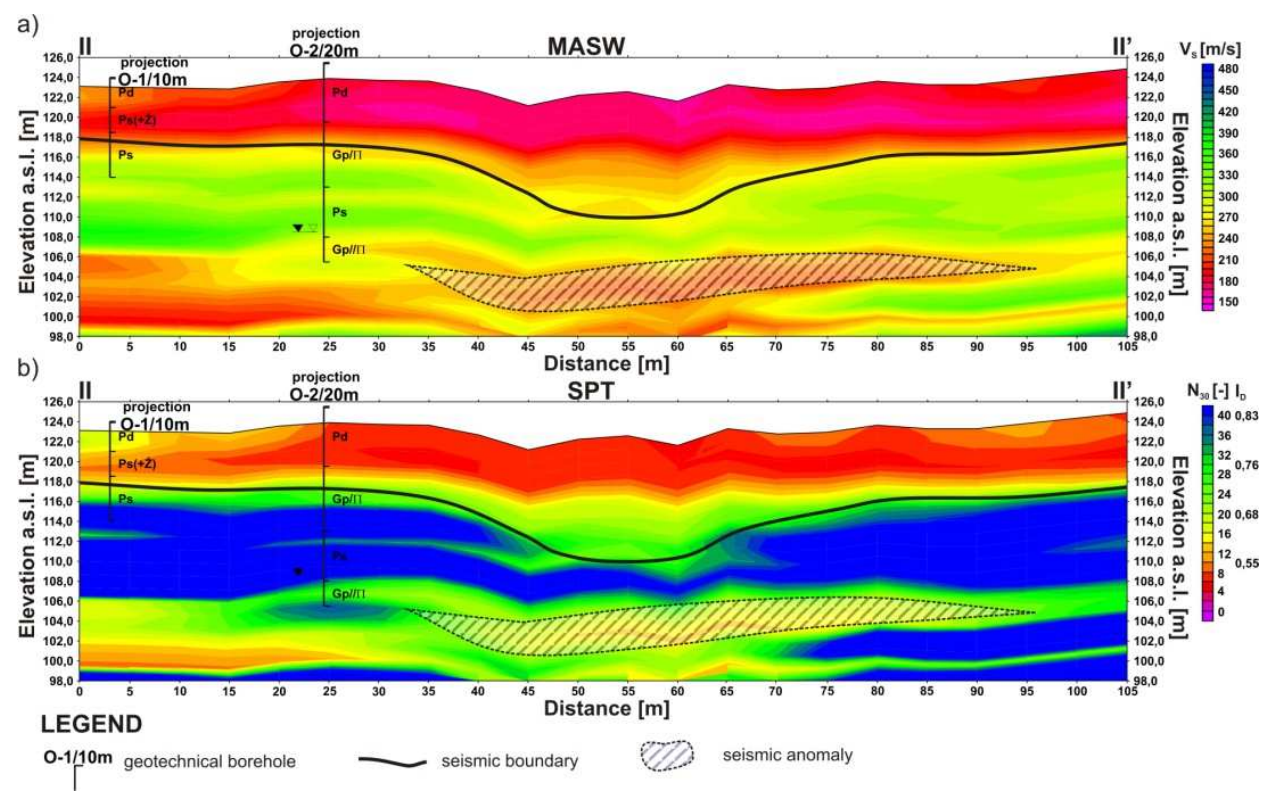

Fig. 6 a) Seismic profile II-II' and b) SPT N30 estimation profile

Rys. 6 a) Profil sejsmiczny II-II' b) estymacja SPT N30 
To supply the geological recognition with more details, seismic surveys were performed with the use of the multi-channel surface wave analysis MASW $[1,16]$. The scope of the survey included the formation of three seismic profiles of the total length of $345 \mathrm{~m}$. Parameters of acquisition were: source type: seismograph Geode-24CH, 10kg sledge hammer , stacking $=10$, line length $=$ $=115 \mathrm{~m}$, source interval $=5 \mathrm{~m}$, number of shotpoints $=25 ; 4,5 \mathrm{~Hz}$ vertical geophones, geophone interval $=5 \mathrm{~m}$, sampling $=0,25 \mathrm{~ms}$, record length $=3 \mathrm{sec}$.

The MASW cross-sections revealed that the wave field was variable. The interpretation allowed establishing the seismic boundary which responds to a footwall of a poorly compacted layer. Seismic cross-section II-II' (Fig. 6.) shows a typical zone revealing the occurrence of unfavorable phenomena. In the central part of the cross-section, the depth of seismic boundary is lowered. In addition, seismic anomaly zone in this area has been marked. This anomaly zone can be related with areas of decreased S-wave velocities. Additionally, in the indicated zone, on the surface of the ground, there are a number of discontinuous deformations in a form of sinkholes.

Moreover, on the basis of the MASW cross-sections, a seismic estimation of the SPT (N30) probing was carried out, which allowed rough evaluation of the alterations in the state of soil compaction [9]. The assessment applies the following relation:

$$
V_{S}=97 \cdot N_{30}^{0,314}
$$

where: $\mathrm{V}_{\mathrm{S}}$ - the $\mathrm{S}$-wave velocity,

N30 - the estimated number of hits with the cylindrical probe SPT (to achieve a 30 -cm progress).

The performed investigation allowed the determination of the boundary of former exploitation area. Generally, it overlaps the area of deformations visible on the surface of the ground. The investigations (drillings and CPT probing) performed a several meters apart from the edges of the sinkholes did not reveal any decompaction of soil down to $20 \mathrm{~m}$ below the surface, which is much deeper that the expected impact range of the planned buildings (ca. $12 \mathrm{~m}$ ). The seismic anomaly occurring in one of the cross-sections, (Fig. 6), complies with the layout and depth of the exploitation galleries.

\section{Investigation of the post-mining area - case study 2}

Three multi-family, 4-floor, buildings (provided with cellars) are planned to be built in a plot in Godlewskiego Street in Zielona Góra. In 1923 - 1927, lignite deposit was extracted in the south half of the plot, with the use of Friedrich Ost I shaft. 


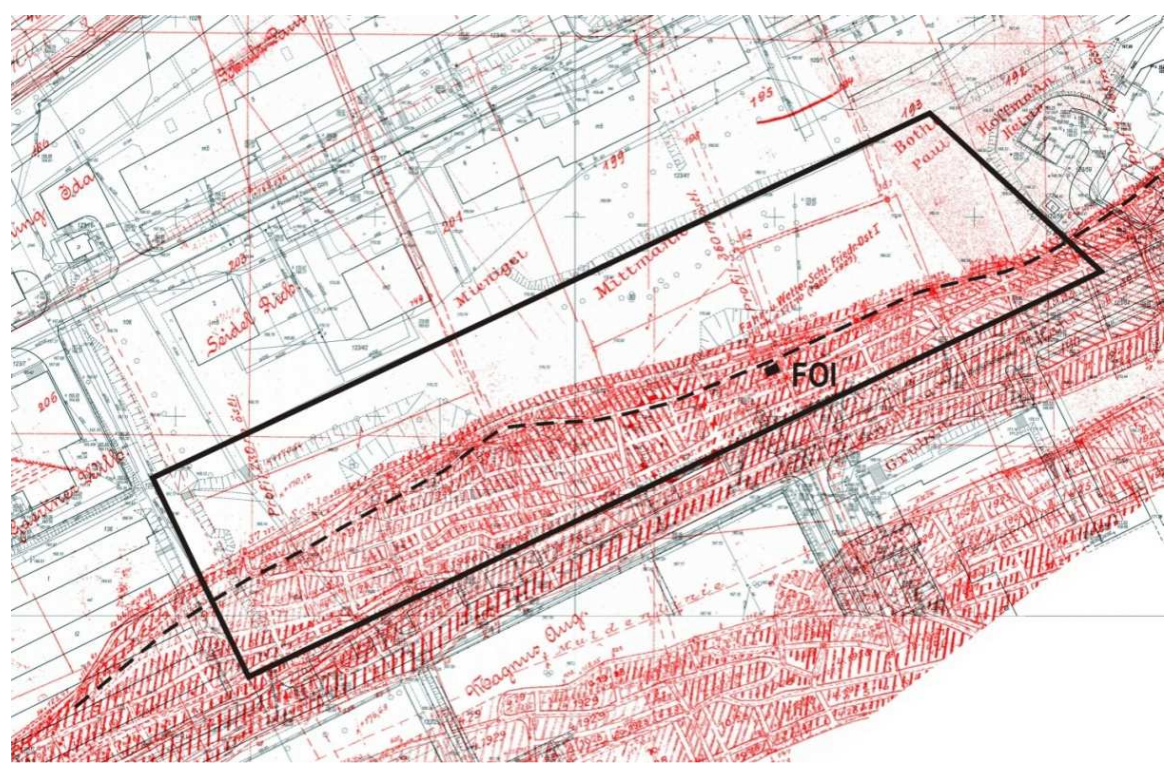

Fig. 7. Overlapped maps: present (black) and old mining (red). Investigated area, hinge line of lignite saddle and Friedrich Ost I shaft (FOI) were marked

Rys. 7. Nałożone mapy: współczesna zasadnicza (czarna) oraz historyczna górnicza (czerwona). Zaznaczono badany teren, przegub siodła oraz szyb Friedrich Ost I (FOI)

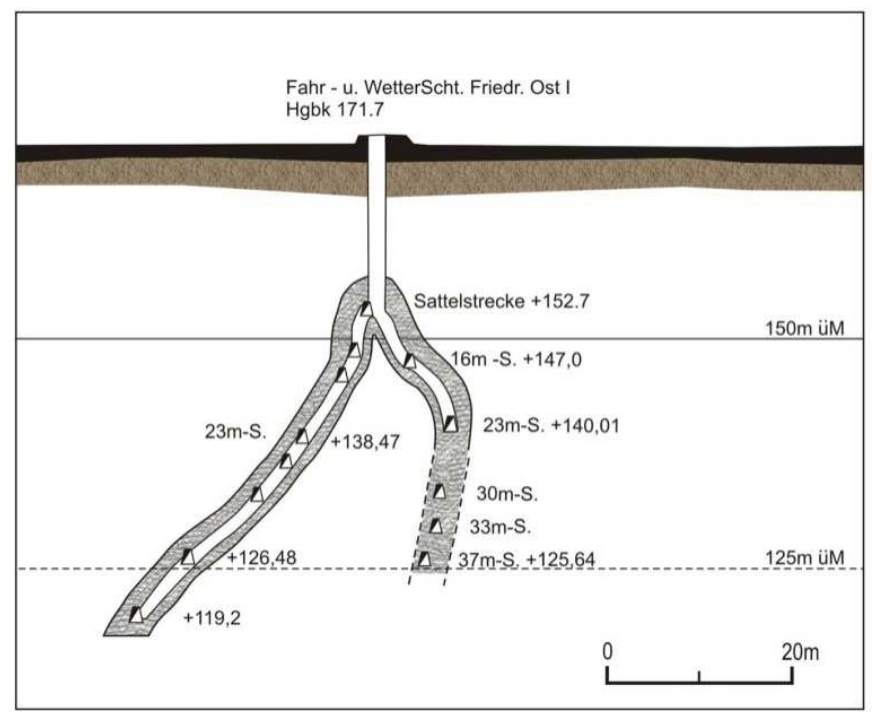

Fig. 8. Cross-section of lignite layer in Friedrich Ost I shaft in Zielona Góra. Explanations: $16 \mathrm{~m}-\mathrm{S}$ - gallery in the depth of $16 \mathrm{~m}$, üM - asl, Hgbk - set ordinate [5]

Rys. 8. Przekrój przez siodło węgla eksploatowane szybem Friedrich Ost I w Zielonej Górze. Objaśnienia: 42 m-S -chodnik na głębokości 42 m, üM -n.p.m. Hgbk - rzędna nadszybia wg [5] 


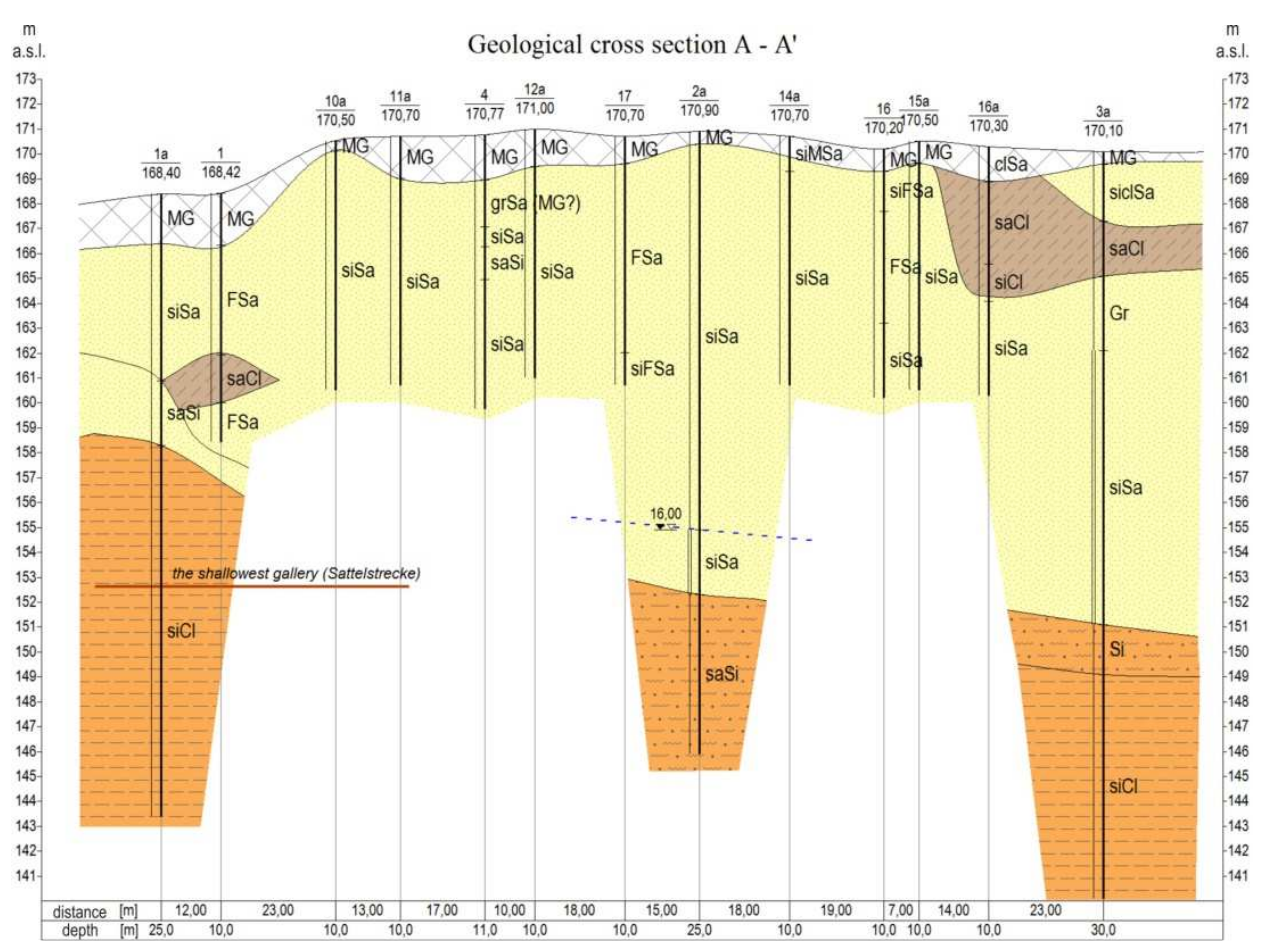

Fig. 9. W-E cross-section of lignite layer in Friedrich Ost I shaft in Zielona Góra

Rys. 9. Przekrój W-E przez siodło węgla eksploatowane szybem Friedrich Ost I w Zielonej Górze

The shallowest gallery (Sattelstrecke), was situated at the depth of ca. $16 \mathrm{~m}$, and the deepest - at $52 \mathrm{~m}$ (beyond the boundaries of the investigated plot). An old mining map (in the scale 1:1000) remained to the present times as well as a cross-section running through the shaft (Fig. 8). A lignite saddle was exploited along the direction SW-NE, and the neighbouring saddle was situated directly to the south. The mining map was calibrated with the contemporary map basing on the pre-war buildings. It allowed to locate a exploitation shaft with the accuracy of app. $5 \mathrm{~m}$.

Geological documentation, prepared in 2006 and based on 22 drillings down to the depth of 10-30 m, questioned whether lignite exploitation took place since the investigation did not find any evidence proving it. However, the remained mining maps (of which the author of the documentation had not known) do not allow such statement. The surface of the area has been strongly changed in the post-war years, there are no characteristic deformations. In 2015, in order to clarify the geological and engineering conditions, MASW survey was carried out, followed by additional drillings and dynamic probing. The subsoil includes embankments, mainly sandy, with thickness up to $7.5 \mathrm{~m}$. Beneath, there are mainly silty sands, fine or medium size, medium-compacted, more than $20 \mathrm{~m}$ 
thick. There are places where boulder clay interbeddings can be found, up to $7 \mathrm{~m}$ thick. Under the Pleistocene sediments, there are Miocene sediments - silts and clays. The deposits form the mentioned before saddles in the SW - NE direction, no lignite was found in any of the drillings (Fig. 9). The table of the underground water occurs at the depth of 13-16 m below the ground surface.

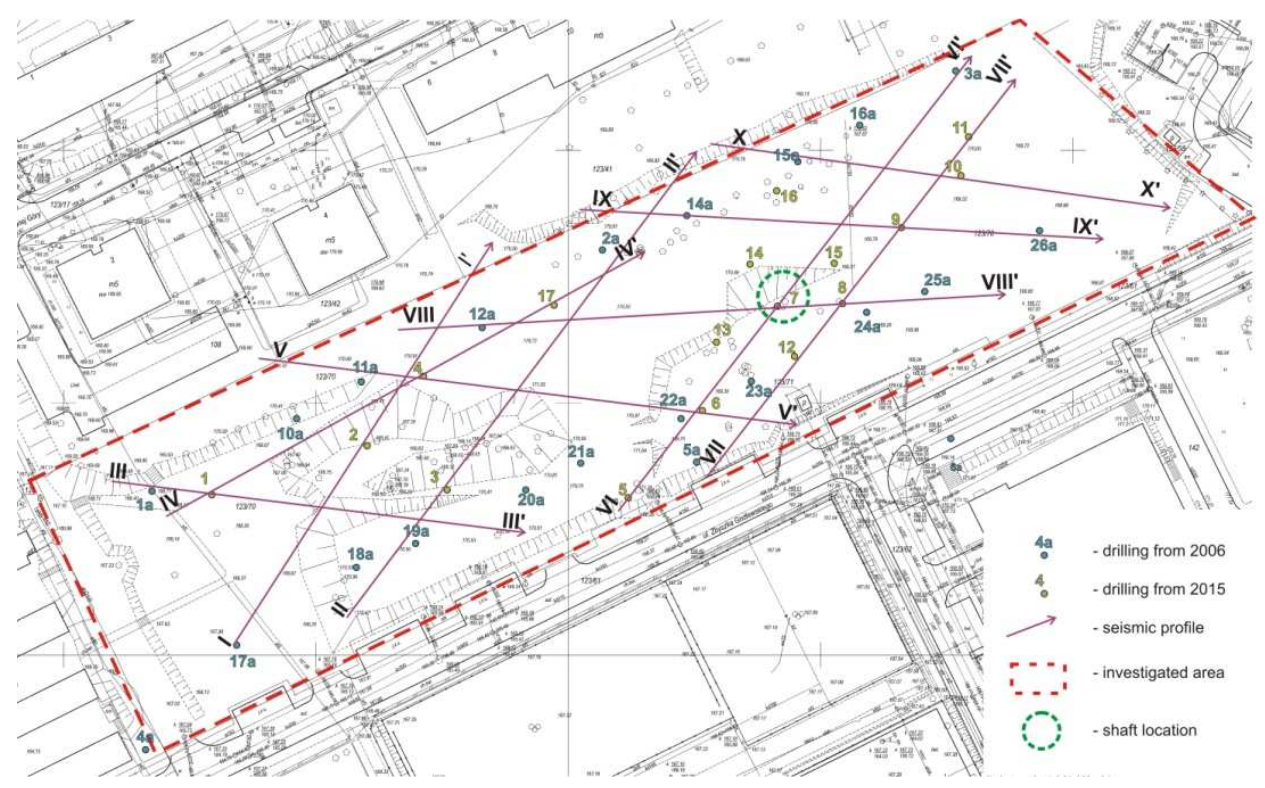

Fig. 10. Location of seismic lines

Rys. 10. Lokalizacja linii profile sejsmicznych

The scope of the seismic surveys (MASW) for the whole investigated area included 10 seismic profiles of the total length of $1150 \mathrm{~m}$ (Fig. 10). Parameters of acquisition were: source type: seismograph Geode- $24 \mathrm{CH}, 10 \mathrm{~kg}$ sledge hammer, stacking $=10$, line length $=115 \mathrm{~m}$, source interval $=5 \mathrm{~m}$, number of shotpoints $=25 ; 4,5 \mathrm{~Hz}$ vertical geophones, geophone interval $=5 \mathrm{~m}$, sampling $=0,25 \mathrm{~ms}$, record length $=3 \mathrm{sec}$.

The scope of the geophysical survey included the recognition of the possible presence of voids (old workings) or zones of smaller soil density in the subsoil of planned buildings. Its objective was also to verify the location of shaft Friedrich Ost I. The location was initially determined on the basis of archive materials (Fig. 7) to avoid constructing the planned multi-family houses in the vicinity of the shaft.

In the neighbourhood of the expected location of shaft Friedrich Ost I, two seismic profiles (crossing each other) were performed. Both for profile VIIIVIII' (Fig. 11) and VII-VII', no disturbances were found in the soil structure. In order to verify the investigation results, a borehole $(\mathrm{O}-8)$ was drilled down to the 
depth of $14 \mathrm{~m}$ at the intersection of the profiles (assumed location of the shaft). The investigation, too, did not confirm the presence of the shaft in this location. However, the boreholes performed closest to the expected location of the shaft revealed artificial sediments up to $7 \mathrm{~m}$ thick. Due to the lack of precise information on the location of the shaft, a safety zone was established on the bases of cartographic data. The zone was excluded from development.
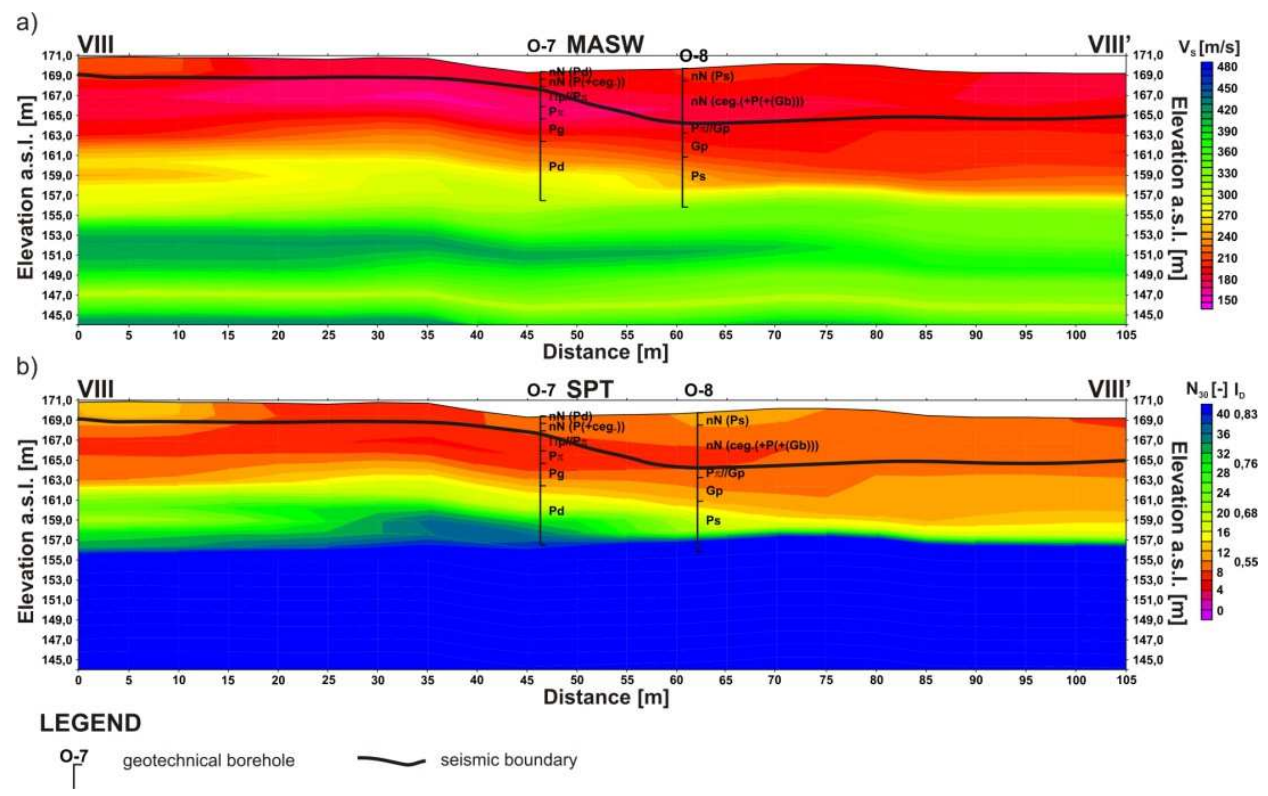

Fig. 11. a) Seismic profile VIII - VIII' and b) SPT N30 estimation profile Rys. 11. a) Profil sejsmiczny VII-VIII', b) estymacja SPT N30

The excavations for foundations revealed the occurrence of area subsidence to the depth of more than $6 \mathrm{~m}$. They were filled with debris and other waste from previous building sites (from the 1970s). The subsidence may be of a postmining origin.

\section{Summary}

The post-mining areas in Zielona Góra are located in the centre of the town, and until recently they were mainly wastelands. Currently, they are intended to be turned into housing estate areas, which makes it necessary to determine the geological - engineering conditions, in order to safely plan the erection of the buildings. There are neither elaborated procedures for such investigations nor are any comparisons of the effectiveness of various geophysical methods in such geologic conditions (mining of glaciotectonic disturbed lignite deposits). After 
wooden casings had been removed, an immediate collapse of the soil took place, followed by the flooding of the remained void by saturated sands. After almost 100 years since the termination of exploitation, almost all the gobs have been squeezed, and the deformations of the surface of the area have ceased. However, sinkholes, which have appeared in the last few years, prove explicitly that the process has not ceased everywhere. Most probably, the wooden casing might have not been removed everywhere, which was proved by the results of drillings (wooden remaining were found in some tested wells) [17]. The occurrence of sinkholes after such a long time of the exploitation termination can be explained by considerable compression strength of the casing (the load of the overburden) and the absence of the atmospheric oxygen (causing timber decay) due to the fact that the workings were flooded.

The seismic method (MASW), applied in the described case studies, did not always confirmed the expected results. Its effectiveness is conditioned by e.g. type of soil or by the prior identification of the location of the shaft (since it determines the precise location of the seismic profiles). It should be noted that the assumed location of shaft Friedrich Ost I (discussed in the second case study) was marked on the map in the process of recalculation of the ordinates from the old maps which were in different geodetic coordinates. It could cause some inaccuracies in establishing the real location of the shaft, and thus resulted in its "omission" by seismic profiles. However, the seismic survey aimed at recognition of the subsoil of the whole investigated area, and were not restricted to the shaft searching.

The factor hindering the geological - engineering recognition is also the level (depth) at which the exploitation took place. It sometimes exceeded $50-$ $70 \mathrm{~m}$ below the ground. There is no sense to proceed drillings at such depths because of width of exploitation gallery (with rooms) - ca. 5 meters.

The described geological - engineering investigations did not answer to all the questions. However, they allowed determination of the soil parameters necessary for designing the planned buildings. Some of the buildings are being erected at the moment.

\section{Literature}

[1] Billington N. et al.: 2D MASW surveys to evaluate subsurface stiffness. Presentation at 7th Annual Technical Forum. Schnabel Engineering. 2007, presentation, https://pl.scribd.com/document/303382235/04-Billington-Geohazard-2007-NEW.

[2] Chrastek J.: Możliwość oddziaływania starych wyrobisk górniczych Dolnego Śląska na zagospodarowanie powierzchni terenu. Prace Naukowe Ośrodka Badań Prognostycznych Politechniki Wrocławskiej Nr 3, Wrocław. 1974.

[3] Czechowski M.: Gospodarcze i techniczne zagadnienia związane z węglem brunatnym [W:] Węgiel brunatny w Zachodniej Polsce, Katowice. 1949.

[4] Gontaszewska A. Podziemna eksploatacja węgla brunatnego na Ziemi Lubuskiej dawne górnictwo, współczesny problem. Przegląd Górniczy 10, 2015, pp. 1-8. 
[5] Gontaszewska A.: Rozpoznanie geologiczno-inżynierskie na terenie dawnej podziemnej eksploatacji węgla brunatnego - przykład Zielonej Góry. Bezpieczeństwo Pracy i Ochrona Środowiska w Górnictwie 6, 2016, pp. 7-16.

[6] Gontaszewska A., Kraiński A.: „Consolidierte Grünberger Gruben" - zarys historii [W:] Dzieje górnictwa - element europejskiego dziedzictwa kultury, t.3, Wrocław, 2010, pp. 111-122.

[7] Gontaszewska A., Kraiński A.: Deformacje powierzchni terenu na obszarze dawnego podziemnego górnictwa węgla brunatnego w okolicy Zielonej Góry [W:] Wybrane problemy badań geologicznych i hydrogeologicznych dla górnictwa i energetyki, GIG Katowice. 2012, pp. 108-119.

[8] Gumprecht A.: Zasady górnictwa węgla brunatnego, Państw. Wyd. Tech., Katowice. 1952.

[9] Imai T., Tonouchi, K.: Correlation of N-value with S-wave velocity and shear modulus, Proceedings of the Second European Symposium on Penetration Testing Amsterdam. 1982, pp. 67-72.

[10] Klein J.: Handbuch für den deutschen Braunkohlenbergbau, I Band, 1927, Halle.

[11] Kohl J.: Die Entwicklung eines neues Verfahrens für den Abbau der Braunkohlenflöze in Felderbereich der Gewerkschaft „Bach“ in Ziebingen, Braunkohle 46, 1936, pp. 832-837.

[12] Kotyrba A., Frolik A., Protas Ł., Siwek S.: Zagrożenia pogórnicze na terenach dawnych podziemnych kopalń węgla brunatnego w rejonie Piły - Młyna (województwo Kujawsko-Pomorskie, Przegląd Górniczy 7, 2012, pp. 58-66.

[13] Kozacki L.: Przeobrażenia środowiska geograficznego spowodowane wgłębnym górnictwem węgla brunatnego na obszarze Środkowego Pododrza, Seria Geografia nr 21, UAM, Poznań, 1980.

[14] Peugler H. (red): Die alten fünf Bergwünsche. 100 Jahre Grünberger Braunkohlengruben. Grünberger Verlags-Druckerei Paul Keppler, Grünberg, 1940.

[15] Skoczylas J.: Z dziejów poszukiwań i prób eksploatacji węgla brunatnego w Jerce (Wielkopolska). Przegląd Górniczy 2, 2011, pp. 82-87.

[16] Stokoe K.H. II Rix G.J., Nazarian S.,: In Situ Seismic Testing with Surface Waves, Proceedings, 12th International Conference on Soil Mechanics and Foundation Engineering, Rio de Janeiro, 1989, pp. 331-334.

[17] Szajna W., Gontaszewska A.: Shallow site investigation of Quaternary sands in side and in the vicinity of a sinkhole in the former lignite mining area in Zielona Góra (western Poland), Geological Quarterly 59 (2), 2015, pp. 347-357.

\section{BADANIA GEOLOGICZNO-INŻYNIERSKIE ORAZ SEJSMICZNE NA OBSZARACH DAWNEGO GÓRNICTWA WĘGLA BRUNATNEGO - DWA PRZYPADKI Z TERENU ZIELONEJ GÓRY}

\section{S u m m a r y}

Artykuł przedstawia badania, jakie przeprowadzono na dwóch przykładowych działkach przeznaczonych dla zabudowy wielorodzinnej leżących na terenie dawnego górnictwa węgla brunatnego w Zielonej Górze. Było to górnictwo podziemne, działające w latach 1840-1948. Węgiel 
brunatny eksploatowany był metodą filarowo - komorową, na zawał, powodując powstawania na powierzchni deformacji terenu. Dla niektórych fragmentów miasta zachowały się mapy górnicze.

W pierwszym przypadku brak było szczegółowych danych górniczych. W celu rozpoznania budowy geologicznej pod projektowany budynek wielorodzinny, 7-kondygnacyjny wykonano geofizyczne badania sejsmiczne techniką wielokanałowej analizy fal powierzchniowych MASW. Wykonano 3 profile sejsmiczne. Wykazały one kilka niewielkich stref cechujących się niższymi wartościami prędkości fal sejsmicznych poprzecznych S. W celu weryfikacji, czy strefy obniżeń prędkości związane są np. z obniżonym zagęszczeniem gruntu wskutek zawału stropu nad komorami eksploatacyjnymi wykonano odwierty do głębokości wskazanej badaniami geofizycznymi. Wykonano także sondowania sonda CPTu oraz sondowania dynamiczne. Uzyskane dane pozwoliły na określenie parametrów podłoża koniecznych do bezpiecznego zaprojektowania posadowienia budynku. W drugim przypadku dostępna była mapa górnicza z lokalizacją szybu oraz głównych chodników.

Keywords: górnictwo węgla brunatnego, Zielona Góra, badania sejsmiczne, wielokanałowa analiza fal powierzchniowych, MASW, sejsmiczna estymacja SPT (N30)

Przestano do redakcji: $11.04 .2017 \mathrm{r}$.

Przyjęto do druku: $28.04 .2017 \mathrm{r}$. 